DOI: https://doi.org/10.32839/2304-5809/2019-4-68-22

UDC 821.111-31’06.09

Timofieieva Viktoriia

Oles Honchar Dnipro National University

\title{
THE PRINCIPLES OF INTERTEXTUAL TRUTH IN “CHATTERTON” BY P. ACKROYD
}

Summary. The analysis of the intertext functions in biographical novels by P. Ackroyd also Chatterton has been reviewed in this article. Using citations, reminiscences, and allusions creates a factual structure of the works and becomes a particular tool of the hero's characteristic. Its purpose is to destroy the stereotyped images. Metanarrative seeks to legitimize itself as the only ideology showing the way of Truth, neglects the other narratives, and functions violently to suppress and control the individual subject disregarding individual or cultural differences. The intertext helps P. Ackroyd to comment the works of his heroes and to include them in the cultural paradigm. As a result, the structure of the biographical novel becomes open and allows of different interpretations. The results of the study can be applied in the course of lectures on the history of modern English literature and courses devoted to the study of postmodern novel poetics.

Keywords: Chatterton, biographical novel, intertextuality, reminiscence, allusion, citation

Tімодеєва B.C.

Дніпровський національний університет імені Олеся Гончара

\section{ПРИНЦИПИ ІНТЕРТЕКСТУАЛЬНОЇ ПРАВДИ В «ЧАТТЕРТОНІ» П. АКРОЙДА}

\begin{abstract}
Анотація. У статті подано аналіз функцій інтертексту в літературно-біографічних романах П. Акройда, зокрема Чаттертоні. Використання цитат, алюзій та ремінісценцій створюе фактичний каркас творів і є засобом характеристики героя, мета якого - зруйнувати складний стереотипний образ. Метаноррація прагне легітимізувати себе як єдину ідеологію, що показує шлях істини, нехтує іншими нарративами і насильно фрункціонуе, щоб придушити і контролювати індивідуальний суб'єкт, не звертаючи уваги на індивідуальні чи культурні відмінності. За допомогою інтертексту Акройд, паралельно з розвитком дії, коментує творчість своїх героїв, вписуе їх в певну культурну парадигму. В результаті структура роману-біографії стає відкритою і допускае безліч інтерпретацій. Ще однією формою інтертекстуальності в романі стають «історії», які звертаються до техніки масової літератури. Включаючи у свою художню практику елементи масового мистецтва постмодернізм в той же час оріентується на жанри високої, або немасової літератури, завойовуючи тим самим дуже широку і різноманітну читацьку аудиторію. Теоретики постмодернізму визначають це явище як принцип «подвійного кодування». Будь-яке оповідання існує у переплетенні різних кодів, викликаючи «читацьке нетерпіння» у бажанні пізнати вислизаючі «відтінки сенсу». 3 принципом «подвійного кодування» пов'язаний «іронічний модус» оповідання, що означає, що у своєму прагненні зруйнувати мовні (ототожнювані з розумовими) стереотипи сприйняття читача, постмодерністи звертаються до використання і пародіювання жанрів і прийомів масової літератури, іронічно переосмислюючи їх стиль. Пародіювання дослідження літературознавства, використання літературних алюзій в романі відбивають інтерес автора до такої важливої складової постмодерністської парадигми, як гра. Сполучаючи елементи різних жанрів, високого (роман про творчу особу) і масового (детектива), поєднуючи історико-фрілологічну достовірність з вигадкою, інтертекстуальність з пародією, висуваючи в якості ведучих сучасні фрілологічні і естетичні проблеми, письменник фрілолог формуе нову модифікацію романної форми - фрілологічний роман. Результати дослідження можуть бути застосовані при викладанні курсу лекцій з історії новітньої англійської літератури та спецкурсів, присвячених вивченню поетики постмодерністського роману.
\end{abstract}

Ключові слова: Чаттертон, біографічний роман, інтертекстуальність, ремінісценція, алюзія, цитування

Deter Aroyd is one of the most interesting classics of modern English literature along with J. McUen, J. Barns, and others. His work includes works of various genres ranging from lyrical poems to historical detective stories, but Acroyd gained fame primarily due to artistic biographies of writers and poets. At the same time, the genre of the biography Akroyd interprets in a postmodern vein, actively using one of the basic principles of the corresponding poetics - intertextuality.

In this regard, the study of ways of organizing text on the basis of this principle in the context of the specifics of the novel-biography genre (literary and "alternative") is of particular relevance. Consideration of Akroyd's creativity in this aspect determines the novelty of our work, since at present there are not so many scientific studies devoted to the work of this English writer in Russian literary studies (the works of V.V. Strukov, I.A. Dudinoy, E.S. Klimenko, O.A. Naumova, A.M. Zverev, O.Yu. Akhmanova and I.Yu. Popova).
The subject of scientific consideration was primarily the genre originality of Akroyd's works (the problem of the biographical genre was considered by E.V. Ushakova and A.V. Shubina, the detective story by O.Yu. Akhmanov), as well as the concept of "Englishness" - national identity - in the context of postmodern ideas (E.G. Petrosov). The monograph of V.Strukov, which has become classical, is devoted to the peculiarity of the poetics of Akroyd. He builds his reasoning around the concept of "self-reflection novel" - a work about a creative person who openly engages the reader in the process of creating a book [4, p. 18], but at the same time does not pay enough attention to the study of the intertextual layer of Akroyd's novels, which view, is decisive for the narrative model of the writer.

The scientific and practical significance of the work lies in the proposed unified concept explaining the peculiarities of using the principle of intertextuality in the work of Aroyd. The article suggests a corpus of the studied novels of the au- 
thor as a holistic hypertext, subject to the general semantic and stylistic laws. The materials and conclusions presented in this work can be used in the course of further research in the field of postmodernism theory, in studying the works of both the researched author, and contemporary writers, while reading general courses on the history of foreign literature of the second half of the twentieth century, special courses in modern English literature, as well as in the preparation of textbooks on these topics.

The term "intertextuality" was introduced by Y. Kristeva on the basis of the analysis of the concept of the "polyphonic novel" by M. Bakhtin, which recorded the phenomenon of the dialogue of the text with texts preceding and parallel to it in time. In postmodernism, the interaction of a text with a symbolic background acts as an important condition for meaning formation: "every word (text) is ... the intersection of other words (texts)", "the dialogue of different types of letters - letters of the writer himself, letters of the recipient (or character) and finally, letters formed by the current or previous cultural context" [5, p. 23]. According to R. Bart, "the basis of the text is ... its output in other texts, other codes, other signs", and, in fact, the text - both in the process of writing and in the process of reading - "is the embodiment of many other texts, infinite or, more precisely, lost (lost traces of their own origin) codes" [2, p. 67]. Thus, "every text is an intertext; other texts are present in it at various levels in more or less recognizable forms ... Each text is a new fabric woven from old quotes. Scraps of old cultural codes, formulas, rhythmic structures, fragments of social idioms, etc. - they are all absorbed by the text and mixed in it, since there is always a language before and around the text” [2, p. 68]. Meaning arises precisely as a result of interconnection of these semantic vectors, which bring them into a broad cultural context, acting in relation to any text as an external semiotic environment. The inclusion in the text of motives, allusions and reminiscences from other works, on the one hand, is an illustration of the principle of nonselection, and on the other, it creates an image of a single hypertext of culture.

Throughout the novel, we can see the power of language in forming self, public; writers and poets gain their very identity from text and language and the entire public see the reality of the golem through the newspaper's scoops. Ackroyd shows incompatibility between intention of the speaker and the meaning inferred from the language in order to show distrust in language and its capability to represent the true ideas of the speaker. Throughout the novel we can see mismatch between outside world/the objects/signified and language/the signifier, so the relation between idea/object and language is inconsistent and conventional not $\mathrm{s}$ and inherent. The concept of originality is destabilized in Ackroyd's novels. Originality is not such a thing, as Romantic Movement believed to be, everything could be at the same time original as well as a copy and an imitation. In Chatterton introducing the idiot boy refers to the metanarattive of Enlightenment with its emphasis on reason and human mind. The idiot child, who stands for human being in the enlightened age, is abandoned by his parents.
The idiot boy is a macro cephalic with big head. Head is the place of reason and this bigness of head and weakness of body is at the same time the symbol of great reason and great ambition, while ironically he is an idiot.

Ackroyd deviates from the biographical account of Chatterton which is written on the first page of the novel and gives different version of the same events and by this way he pokes fun at the verisimilitude of any historical and documentary account. This disbelief in ultimate "Truth" reflects postmodern distrust in Grand Narratives. Historical metafictions such as Chatterton represents history and narratives of the past events and makes it neither believable nor unbelievable in order to show that there is no historical fact but merely "brute events of the past" [5, p. 57]. There are different versions of Chatterton's biography and each biography describes a quiet different poet: the original biography of Chatterton written on the first page of Ackroyd's Chatterton depicts a hopeless Chatterton at the age of eighteen who poisoned himself by drinking arsenic in water when his prospective patron died and he found himself penniless and without prospects. Another version of Chatterton's biography is that he died at the age of eighteen, but he did not commit suicide, his death was merely an accident "a wrong mixture of opium and arsenic, indeed to cure a venereal disease" [3, p. 25]. This version of biography narrates rather different story: he is not described as a depressed penniless poet; instead he was happy and full of energy seeking to improve his health. This version is discovered by Charles when he saw a picture depicting a middle-aged Chatterton on his death bed. In order to know the true history of Chatterton he searches through some documents and diaries supposedly written by Chatterton. The memoirs say that Chatterton is no longer a poet who died young and glorious, but a hack who continued a sordid trade with his partner. This was the document which Charles Wychwood had carried back with him. It is released that each biography depict a quite different poet these biographies are full of contradictions so no one seemed to be certain. At first, Charles had been annoyed by these discrepancies but then they exhilarated him: for it meant that, anything became possible. "If there were no truths, everything was true" [1, p. 127].

It is precisely the topic of "representation" that constitutes the main concern in Chatterton and it is one of the issues most frequently questioned by Postmodernist writers. Chatterton is a novel, which self-consciously weaves an intricate web of texts in such a way that anywhere in the story the reader is bound to find a construction, be it visual or narrative.

Charles Wychwood finds two texts, the portrait and the manuscripts, and he, as reader, chooses to interpret both of them as mimetic representations. He willingly suspends his disbelief and enters the story he himself has constructed with the two texts. When we, readers, discover with Philip Slack that the portrait and the manuscript are part of a joke Old Joynson decided to play on Chatterton's memory by faking "the work of a faker and so confuse for ever the memory of Chatterton" [1, p. 221], we are forced to wonder how many traces of the past are real or fabricated. 
Both texts are "representations" but representations that are questioned as such. As Linda Hutcheon states in The Politics of Postmodernism, "the very word representation unavoidably suggests a given which the act of representing duplicates in some way" [4, p. 32]. That is also the case here: there is a "given" that is represented in the portrait and a "given" (a story) for the narrative representation of the manuscripts. The status of both "givens" is not questioned. It is the sort of mimetic assumptions about representation that are challenged, "its transparency and common-sense naturalness" [4, p. 32].

Postmodernism adopts a systematic disbelief of deeply rooted traditional ideologies and theories. Postmodernism is equivalent to a reaction against an ordered idea about the world and hence against settled notions about the form and meaning of texts. This study has tried to display how Ackroyd questions the metanarratives and the decentring of the cultural authority. It also shows that the world around us should not be seen as a totalizing sequence but in fragmented episodes. For postmodernists neither reality nor meaning can ever definitively be hold fast as truth rather every description of reality, any recognition of meaning is always an interpretation and a conditional construction. There can be no one truth, no one and only true narrative, different way to obtain knowledge is pos- sible yet there is no one correct mode of knowledge or way of knowing; there are a variety of opposing discourses that reach truth. In this novel the legitimacy of history and historiography as informative is questioned thematically as well as structurally. The authenticity of any historical narratives-personal historical narratives such as autobiography and biography- become decidedly unstable. In Chatterton there are several different accounts of Thomas Chatterton's death that are presented in different narratives by this way Ackroyd seeks to emphasize the interpretive quality of history.

In general, it can be concluded that in the Chatterton of P. Akroyd the intertext may be present in the form of hidden or explicit quotations, references to historical and literary facts, imitations of the style of a particular author. Most often, reminiscences are used not only to create an image of the hero, but also to simultaneously destroy his usual perception, myth; they also allow the English writer, while preserving the fiction of the narrative, to simultaneously comment on the work, analyze the hero's work and thereby enlighten the reader. But the use of reminiscences is also part of the philosophy of P. Akroyd, for whom in the knowledge of the truth of history and life is not the primary fact, but the text that preserves human culture and memory.

\section{References:}

1. Ackroyd P. (1993). Chatterton / P. Ackroyd. London : Penguin Books. 249 p.

2. Bart R. (1994). Izbrannye raboty: Semiotika. Pojetika. Moskva : IG Progress. 616 p.

3. Hänninen Ukko (1997). Rewriting Literary History: Peter Ackroyd and Intertextuality. Helsinki : University of Helsinki. $128 \mathrm{p}$.

4. Hutcheon L. (1988). A Poetics of Postmodernism: History, Theory, Fiction. London \& New York : Routledge. 288 p.

5. Shubina A.V. (2009). Problema biograficheskogo zhanra v tvorchestve Pitera Akrojda : avtoref. dis. ... kand. filol. nauk : 10.01.03 / A.V. Shubina; Rossijskij gosudarstvennyj pedagogicheskij universitet im. A.I. Gercena. SPb. 200 p. 